(C) 1984. The Genetical Society of Great Britain

\title{
PATTERNS OF GENETIC VARIATION IN A GROUP OF PARASITES, THE AUSTRALIAN REPTILE TICKS
}

\author{
C. M. BULL*, R. H. ANDREWS* AND M. ADAMS $\dagger$ \\ * School of Biological Sciences, Flinders University, Bedford Park, South Australia, Australia \\ $\dagger$ Evolutionary Biology Unit, S.A. Museum, Adelaide, South Australia, Australia
}

Received 30.iii.84

\section{SUMMARY}

In this paper isoenzyme variation in six species of Australian reptile ticks is used to examine a hypothesis, proposed by Price (1977), that populations of parasites will diverge more rapidly from each other than populations of non-parasites. The data support Price's prediction that parasite populations have low levels of genetic variability. The average heterozygosity per locus was less than 2.5 per cent in each reptile tick species, compared with a mean value of 11.23 per cent for 93 non-parasitic invertebrates (Nevo 1978). Price also predicted large genetic variation between parasite populations, but this was not normally the case within reptile tick species. Where genetic distance was large between populations it could be explained by processes which were not unique to parasites.

\section{INTRODUCTION}

Price (1977) suggested that extensive radiation in parasites has resulted from certain unique aspects of parasite ecology. Because hosts represent small patches of abundant resource within a large inhospitable environment, he proposed that (i) parasite populations are often small, (ii) dispersal between populations is often low, and (iii) reproductive systems leading to a reduction of outbreeding have sometimes developed. He argued that parasite populations with some or all of these characteristics would become genetically different from neighbouring populations more frequently than would populations of non-parasites. In addition he adapted the ideas of Levins (1962) to parasites in suggesting that spatial variation between hosts should lead the parasites to adapt to specific host patches and form populations which are uniform within, but genetically distinct between each other, even without geographical isolation.

We examined Price's (1977) hypothesis about parasite radiation using isoenzyme variation in a group of parasite species, the Australian reptile ticks, to test three predictions: (i) that genetic variation is low within parasite populations; (ii) that genetic variation is high between parasite populations; and (iii) that variation between parasite populations can be independent of geographical isolation. Six tick species were included in the survey, Aponomma hydrosauri, Ap. undatum, Ap. fimbriatum, Amblyomma albolimbatum, Amb. limbatum and an undescribed Amblyomma species from the Flinders Ranges of South Australia. All are three host ticks with each parasite stage (larva, nymph and adult) infesting reptiles (Roberts, 1970).

\section{Materials AND METhodS}

Ticks were collected from reptiles captured at 65 Australian locations (table 1), and returned live to the laboratory. Adult male ticks were used 
TABLE 1

Locations of all tick samples used in the survey

\begin{tabular}{|c|c|c|c|}
\hline \multirow[b]{2}{*}{ Location } & \multirow[b]{2}{*}{ Location number } & \multicolumn{2}{|c|}{ Co-ordinates } \\
\hline & & S & $\mathbf{E}$ \\
\hline
\end{tabular}

Mt. Mary S.A.

Cherry Gardens S.A.

Reevesby Island S.A.

Burra S.A.

Cowell S.A.

Tickera S.A.

Talisker Mine S.A.

Meningie S.A.

Padthaway S.A.

Fishery Bay S.A.

Arno Bay S.A.

Grundy Scrub S.A.

Phillip Island Vic.

Creswick Vic.

Glenisla Vic.

Furner S.A.

South End S.A.

Flinders Island Tas.

Big Heath S.A.

Geelong Vic.

Bremer Bay W.A.

Albany W.A.

Cape Naturaliste W.A.

Arno Bay S.A.

Minnipa S.A.

Balladonia W.A.

Port Kenny S.A.

Eucla W.A.

Esperance W.A.

Madura W.A.

Cleve S.A.

Bremer Bay W.A.

Stirling Ranges W.A.

Kalgoorie W.A.

Geraldton W. A.

Albany W.A.

Cocklebiddy W.A.

Norseman W.A.

Rottnest Island W.A.

Lake Grace W.A.

Yelben W.A.

Perth W.A.

Carnarvon W.A.

Nanga W.A.

Pt. Augusta S.A.

$80 \mathrm{~km}$ NE Birdsville Q1d

95 km S Birdsville S.A.

Parachilna S.A.

Red Cliffs S.A.

\section{AP. HYDROSAURI}

$\begin{array}{rll}1 & 34^{\circ} 06^{\prime} & 139^{\circ} 26^{\prime} \\ 2 & 35^{\circ} 04^{\prime} & 138^{\circ} 39^{\prime} \\ 3 & 34^{\circ} 32^{\prime} & 136^{\circ} 17^{\prime} \\ 4 & 33^{\circ} 41^{\prime} & 138^{\circ} 56^{\prime} \\ 5 & 33^{\circ} 41^{\prime} & 136^{\circ} 55^{\prime} \\ 6 & 33^{\circ} 47^{\prime} & 137^{\circ} 43^{\prime} \\ 7 & 35^{\circ} 38^{\prime} & 138^{\circ} 16^{\prime} \\ 8 & 35^{\circ} 41^{\prime} & 139^{\circ} 30^{\prime} \\ 9 & 36^{\circ} 36^{\prime} & 140^{\circ} 29^{\prime} \\ 10 & 34^{\circ} 55^{\prime} & 135^{\circ} 41^{\prime} \\ 11 & 33^{\circ} 55^{\prime} & 136^{\circ} 34^{\prime} \\ 12 & 37^{\circ} 38^{\prime} & 140^{\circ} 52^{\prime} \\ 13 & 38^{\circ} 28^{\prime} & 145^{\circ} 14^{\prime} \\ 14 & 37^{\circ} 26^{\prime} & 143^{\circ} 54^{\prime} \\ 15 & 37^{\circ} 14^{\prime} & 142^{\circ} 11^{\prime} \\ 16 & 37^{\circ} 25^{\prime} & 140^{\circ} 20^{\prime} \\ 17 & 37^{\circ} 35^{\prime} & 140^{\circ} 07^{\prime} \\ 18 & 40^{\circ} 01^{\prime} & 148^{\circ} 02^{\prime} \\ 19 & 37^{\circ} 06^{\prime} & 140^{\circ} 34^{\prime} \\ 20 & 38^{\circ} 10^{\prime} & 144^{\circ} 21^{\prime} \\ 21 & 34^{\circ} 23^{\prime} & 119^{\circ} 23^{\prime} \\ 22 & 35^{\circ} 00^{\prime} & 117^{\circ} 52^{\prime} \\ 23 & 33^{\circ} 32^{\prime} & 115^{\circ} 01^{\prime}\end{array}$

AMB. ALBOLIMBATUM

$136^{\circ} 34^{\prime}$

$135^{\circ} 09^{\prime}$

$123^{\circ} 37^{\prime}$

$134^{\circ} 41^{\prime}$

$128^{\circ} 53^{\prime}$

$121^{\circ} 54^{\prime}$

$126^{\circ} 00^{\prime}$

$136^{\circ} 30^{\prime}$

$119^{\circ} 23^{\prime}$

$117^{\circ} 47^{\prime}$

$121^{\circ} 28^{\prime}$

$114^{\circ} 37^{\prime}$

$117^{\circ} 52^{\prime}$

$126^{\circ} 06^{\prime}$

$121^{\circ} 47^{\prime}$

$115^{\circ} 30^{\prime}$

$118^{\circ} 28^{\prime}$

$117^{\circ} 40^{\prime}$

$115^{\circ} 51^{\prime}$

$113^{\circ} 40^{\prime}$

$113^{\circ} 48^{\prime}$

AMB. LIMBATUM

$\begin{array}{lll}42 & 32^{\circ} 30^{\prime} & 137^{\circ} 46^{\prime} \\ 43 & 25^{\circ} 22^{\prime} & 139^{\circ} 54^{\prime} \\ 44 & 26^{\circ} 44^{\prime} & 139^{\circ} 23^{\prime} \\ 45 & 31^{\circ} 08^{\prime} & 138^{\circ} 24^{\prime} \\ 46 & 33^{\circ} 20^{\prime} & 137^{\circ} 50^{\prime}\end{array}$


TABLE 1-continued

\begin{tabular}{lccc}
\hline \multicolumn{1}{c}{ Location } & & \multicolumn{2}{c}{ Co-ordinates } \\
\cline { 2 - 4 } & Location number & $\mathrm{S}$ & $\mathrm{E}$ \\
\hline Cockburn S.A. & 47 & $32^{\circ} 05^{\prime}$ & $141^{\circ} 00^{\prime}$ \\
Yunta S.A. & 48 & $32^{\circ} 35^{\prime}$ & $139^{\circ} 34^{\prime}$ \\
Whyalla S.A. & 49 & $33^{\circ} 02^{\prime}$ & $137^{\circ} 35^{\prime}$ \\
Terowie S.A. & 50 & $33^{\circ} 09^{\prime}$ & $138^{\circ} 55^{\prime}$ \\
Broken Hill N.S.W. & 51 & $31^{\circ} 58^{\prime}$ & $141^{\circ} 27^{\prime}$ \\
Clifton Hills S.A. & 52 & $27^{\circ} 01^{\prime}$ & $138^{\circ} 54^{\prime}$ \\
Pitchie Ritchie Pass S.A. & 53 & $32^{\circ} 25^{\prime}$ & $137^{\circ} 56^{\prime}$ \\
Mt. Mary S.A. & 1 & $34^{\circ} 06^{\prime}$ & $139^{\circ} 26^{\prime}$ \\
100 km E Menindie N.S.W. & 54 & $32^{\circ} 25^{\prime}$ & $143^{\circ} 30^{\prime}$ \\
Blinman S.A. & 55 & $31^{\circ} 06^{\prime}$ & $138^{\prime} 40^{\prime}$ \\
& & & \\
Moruya N.S.W. & APONOMMA UNDATUM & $32^{\circ} 55^{\prime}$ & $150^{\circ} 06^{\prime}$ \\
Kinchega N.S.W. & 56 & $32^{\circ} 29^{\prime}$ & $142^{\circ} 21^{\prime}$ \\
& 57 & & \\
Mt. Bundey Station N.T. & APONOMMA FIMBRIATUM & $13^{\circ} 12^{\prime}$ & $131^{\circ} 11^{\prime}$ \\
Pitchie Ritchie Pass S.A. & 58 & & \\
Oraparrina S.A. & AMB YOMMA sp. nov. & $32^{\circ} 25^{\prime}$ & $137^{\circ} 56^{\prime}$ \\
Uno S.A. & 53 & $31^{\circ} 22^{\prime}$ & $138^{\circ} 43^{\prime}$ \\
\hline & 59 & $32^{\circ} 38^{\prime}$ & $136^{\circ} 41^{\prime}$ \\
\hline
\end{tabular}

because they feed very little on host tissue, individuals are large enough for an electrophoretic sample, and they are the most common stage available on many host individuals (Bull, 1978a).

Each tick was homogenised in an equal volume of lysing solution (Baverstock et al., 1977a), and the homogenate centrifuged at $16,000 \mathrm{~g}$ for 10 minutes. The supernatant was then stored in 51 aliquots at $-20^{\circ} \mathrm{C}$. Electrophoresis on "Cellogel" (Chemetron, Milan) was performed as in Baverstock et al. (1977a) and Baverstock et al. (1980).

The loci scored were: Adenosine deaminase (Ada), Adenylate kinase $(A k)$, Enolase (Enol), Glutamate dehydrogenase $(G d h)$, Glutamateoxaloacetate transaminase (Got-1, Got-2), Glucose-6-phosphate dehydrogenase $(G 6 p d)$, Glycerol-3-phosphate dehydrogenase (Gpd), Glucosephosphate isomerase (Gpi), Glutamate-pyruvate transaminase (Gpt), Isocitrate dehydrogenase $(I d h-1, I d h-2)$, Lactate dehydrogenase ( $L d h-1$, $L d h-2)$, Malate dehydrogenase (Mdh-1, Mhd-2), Mannose-phosphate isomerase (Mpi), Nucleoside phosphorylase $(N p)$, Peptidases (Pep A (valine-leucine), Pep B-1, Pep B-2 (Leucine-glycine-glycine) Pep D (phenylalanine-proline)), Phosphogluconate dehydrogenase (6Pgd), Phosphoglycerate kinase $(P g k)$, Phosphoglucomutase $(P g m)$, Pyruvate kinase $(P k)$, Superoxide dismutase (Sod), Triose-phosphate isomerase (Tpi). Not all loci were scorable in all 321 ticks.

Where enzymes were encoded by more than one locus, loci were numbered in order of increasing electrophoretic mobility. Alleles were designated according to electrophoretic mobility with $a$ being the most anodal.

Blood samples were collected by orbital sinus bleeding from the common host species Trachydosaurus rugosus, prepared for electrophoresis as in 
Baverstock et al., 1977a), and run beside tick samples. There were no bands on the gels common to tick and lizard samples, confirming that ingested host enzyme was not being scored as tick enzyme.

For each tick population the expected frequency of heterozygotes at each locus, and the average heterozygosity over all scored loci, were calculated assuming random mating. Autosomal inheritance was assumed for all loci, except Gpi where no heterozygotes were recorded in large samples of male ticks from populations where alternative alleles were present. Since males are the heterogametic sex in Australian ixodid ticks (Oliver and Bremner, 1968), Gpi is probably sex linked. The genetic distance (D)(Nei, 1972) between pairs of populations was calculated with corrections for small sample sizes (Nei, 1978). Dendrograms were constructed by the UPGMA method (Sneath and Sokal, 1973).

\section{Results}

\section{(i) Aponomma hydrosauri}

The 23 sites from where $A$. hydrosauri were collected are shown in fig. 1. Table 2 shows the allele frequencies in those populations at 24 loci, with alleles from 16 to 20 loci recorded in each population. Missing values in table 2 indicate insufficient staining intensity or unavailability of samples from some locations, given that the survey was conducted over two collecting seasons. Calculations of genetic distance were based on 18 loci (the first 15 in table 2 plus the three invariant loci). Five of the loci omitted from the analysis were monomorphic whenever scored. If the same alleles were monomorphic in unrecorded populations, then both the genetic distances and the average heterozygosity per locus have been overestimated in this paper. Because the locus $P e p A$ was omitted from the analysis the genetic distance between eastern and western populations may have been underestimated.

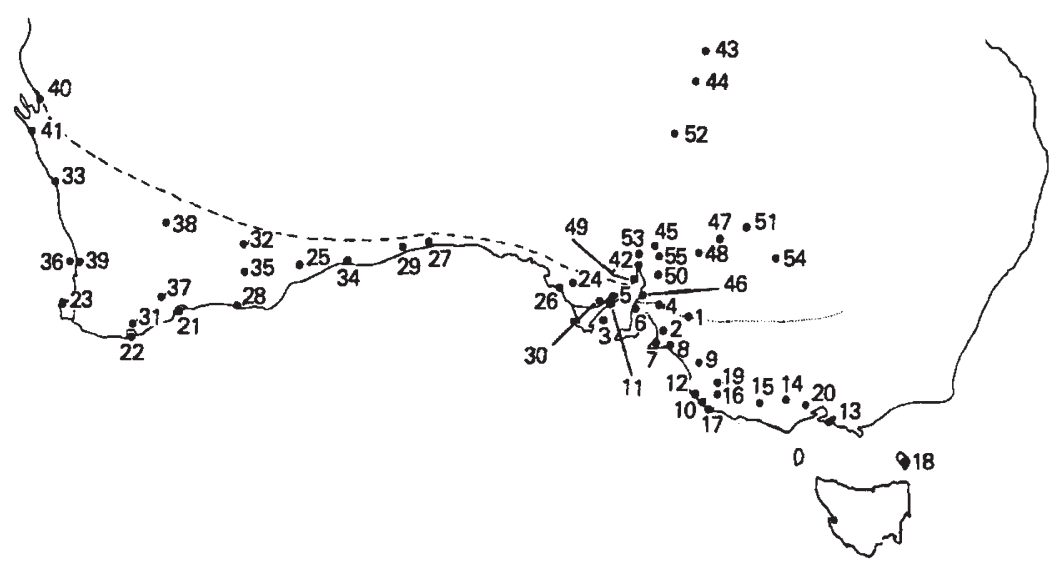

FIG. 1. The collection sites (numbered as in table 1) for Ap. hydrosauri, Amb. albolimbatum and $A m b$. limbatum. The three species have allopatric distributions which abut along the lines on the map. Ap. hydrosauri is found between the southern coast and the dotted line, $A m b$. albolimbatum between the dotted and dashed line, and Amb. limbatum to the north of the other two species (Bull et al., 1981). 
Estimates for the mean heterozygosity per locus are shown for each population in table 2. There were few variable loci, and only four (Ada, $P k, P g m$ and $G 6 p d$ ) were polymorphic in more than 20 per cent of populations.

Over all populations there was an average of 2.47 per cent $( \pm 0.49)$ heterozygosity per locus. There was a significantly higher mean heterozygosity among the 11 eastern populations $(9,10$ and $12-20$ in table 2$)$ $(\bar{x}=4.04 \pm 0.65)$ than among the other 12 populations $(\bar{x}=1.03 \pm 0.44)$ $\left(t_{21}=3.84 ; p<0.001\right)$. The most variable populations were in south eastern South Australia and south western Victoria.

The dendrogram for Ap. hydrosauri populations (fig. 2) shows the three Western Australian populations (21, 22, and 23) separated from all other populations, a result of the fixed difference at the $M d h-1$ locus. Also the Cape Naturaliste population (23), but not the two other Western Australian populations, had a fixed allele difference from eastern populations at the $P e p D$ locus. There may have been an additional fixed difference at the PepA locus.

The populations from central South Australia were separated on the dendrogram from those in south eastern South Australia, Victoria and Flinders Island (fig. 2), because of high frequencies of alternative alleles at two loci, $P k$ and G6pd. Overall, however, genetic distances between eastern populations were low $(\bar{x}=0.051( \pm 0.003) ; n=190$ pairwise comparisons).

In four instances, geographical isolation was not associated with increased genetic distance. The population at Cowell (5) on Eyre Peninsula, was genetically identical to other populations in South Australia from which it is isolated by Spencer Gulf. Reevesby Island (3), off Eyre Peninsula, had a population genetically identical to that at Cowell (5), and other South Australian populations. The population from Phillip Island (13), off the Victorian coast, differed little from populations on mainland Victoria. And on Flinders Island (18), in Bass Strait, there was a high frequency of a unique allele at the Ada locus, but the population was separated from mainland populations by less than 0.05 genetic distance units.

In contrast the population from near Arno Bay (11), differed in allele frequency at two loci ( $\mathrm{Pgm}$ and $\mathrm{Gpi}$ ) from most other populations, including Cowell (5). Cowell and Arno Bay are $50 \mathrm{~km}$ apart within an area of continuous distribution of Ap. hydrosauri (Petney et al., 1982). More detailed collections were made to score Pgm and Gpi allele frequencies (fig. 3). There was a sharp cline from west to east for each locus, and a further new allele Gpi c was found, restricted to one subregion (fig. 3). There was a significantly non-random association of Pgm genotypes with Gpi genotypes among 282 ticks for which both loci were scored $\left(\chi_{2}^{2}=16.41 ; p<0.001\right)$, although this probably resulted from a geographical association of alleles, because in subregions with intermediate frequencies of both alleles, the association of genotypes was random $\left(\chi_{2}^{2}=0.33\right.$; n.s. $)$. Thus there is no evidence of linkage or assortative mating.

\section{(ii) Amblyomma albolimbatum}

The 21 sites from where Amb. albolimbatum were collected are shown in fig. 1. Each population was scored for 19-21 loci (table 3). Variability 


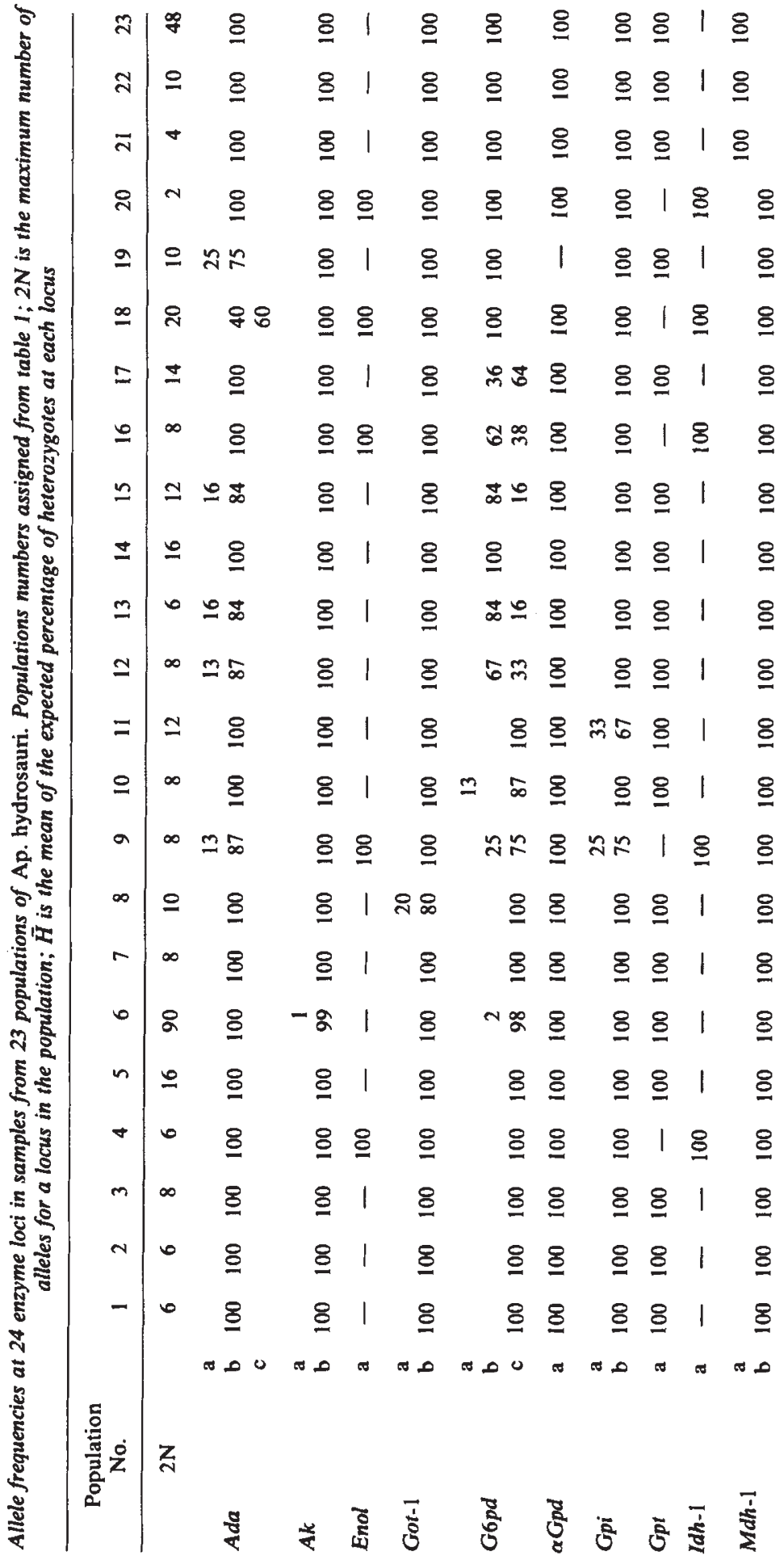




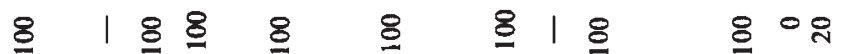

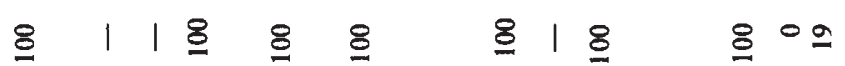
\& $118 \& \approx \approx \& 1 \& \& \dot{\alpha}$ \& 8111 \& 8 \& 8 \& $\&|1| 1 \quad \& \quad \& 1 \&$ 용

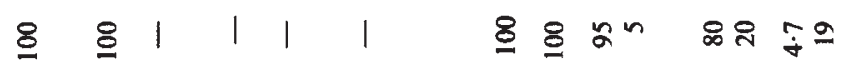

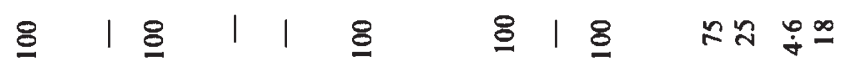
曲

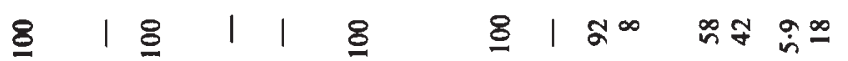

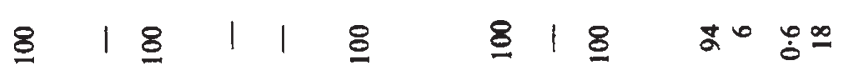
8 1 \& 111 \& $\quad$ \& 1 \& 8

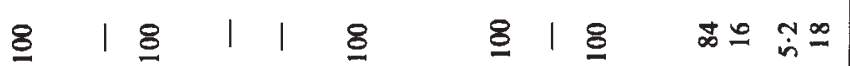

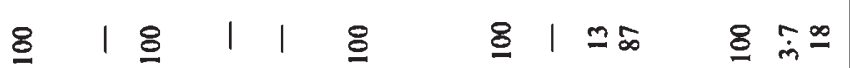

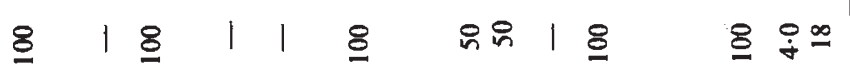

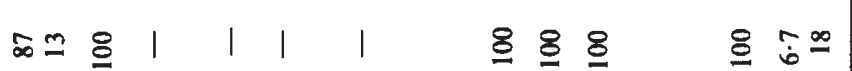

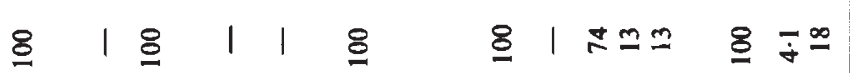

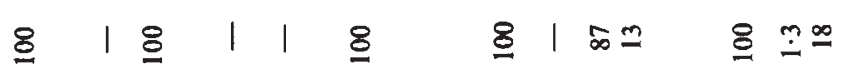

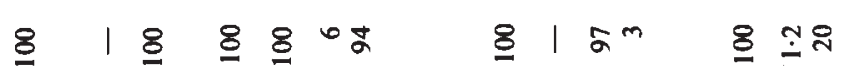
\& 1 \& 1 \& 81 \&

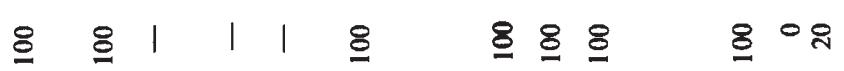
$\& 11 \& 8 \& 18$ \& 809 \& $1 \& 11 \%$

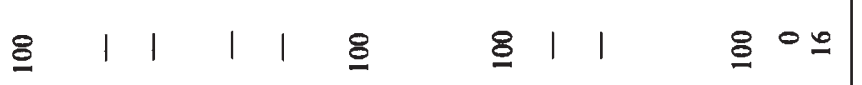

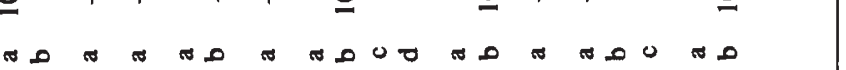
กิ 

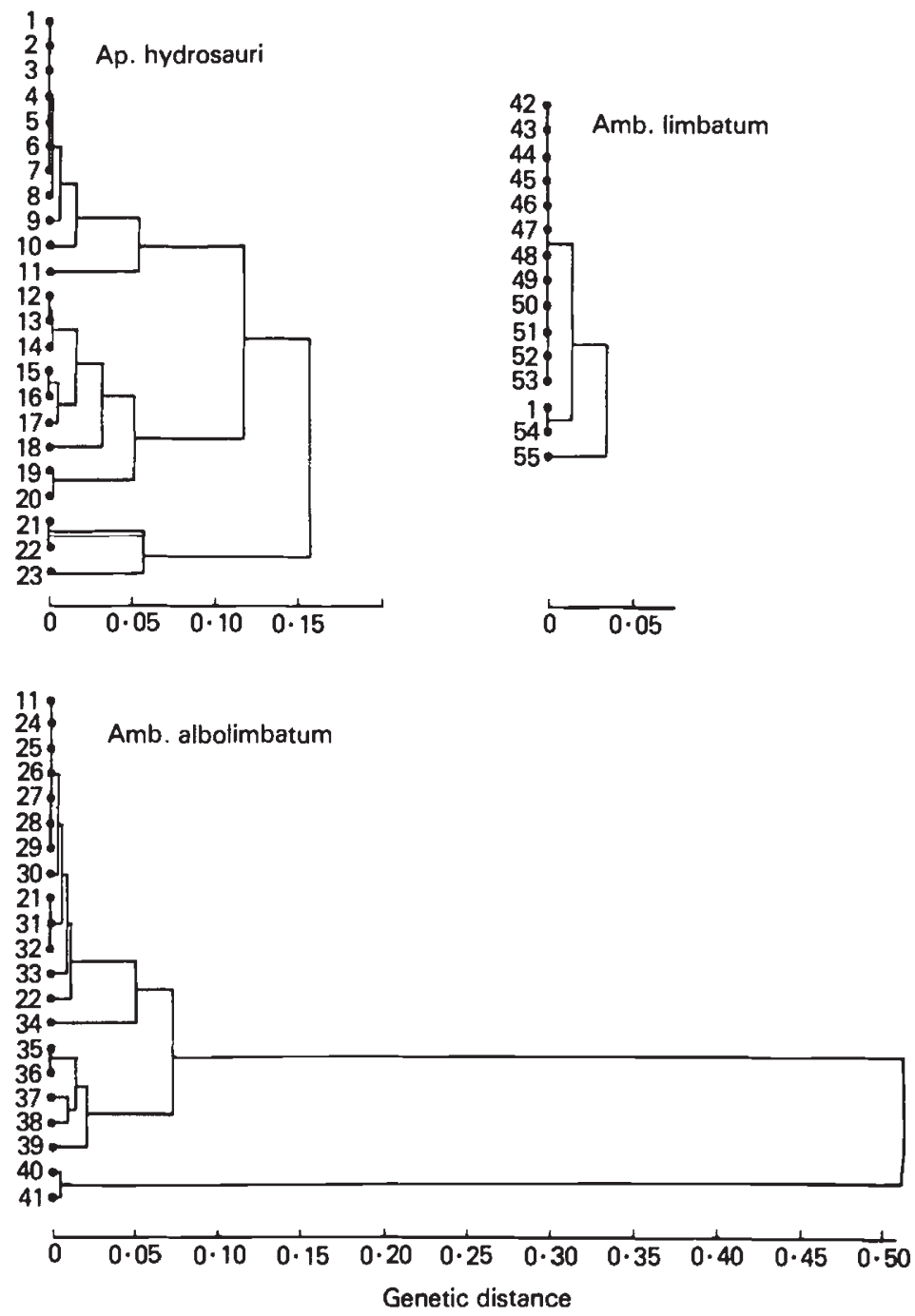

FIG. 2. Dendrograms based on Nei genetic distances between populations of Ap. hydrosauri, $A m b$. albolimbatum and Amb. limbatum. Populations are numbered as in table 1.

within populations was low and only two loci ( $P e p A, P e p B-2)$ were polymorphic in more than 20 per cent of the populations. Over all populations there was an average of $2 \cdot 31( \pm 0.42)$ per cent heterozygosity per locus.

The dendrogram was based on 15 loci recorded for all populations (fig. 2). Two populations (Carnarvon and Nanga $(40,41)$ ) were very similar to each other but widely separated from all other because of fixed or almost fixed gene difference at eight loci ( $A k, G p i, \alpha G p d, I d h-1, N p, P e p D, P k, T p i)$.

The genetic distances among the remaining 19 populations were smaller. In fact these distances may be overestimates because ten loci, at which all sampled populations were fixed for the same allele, were omitted from the analysis. The geographically isolated population on Rottnest Island (36) 


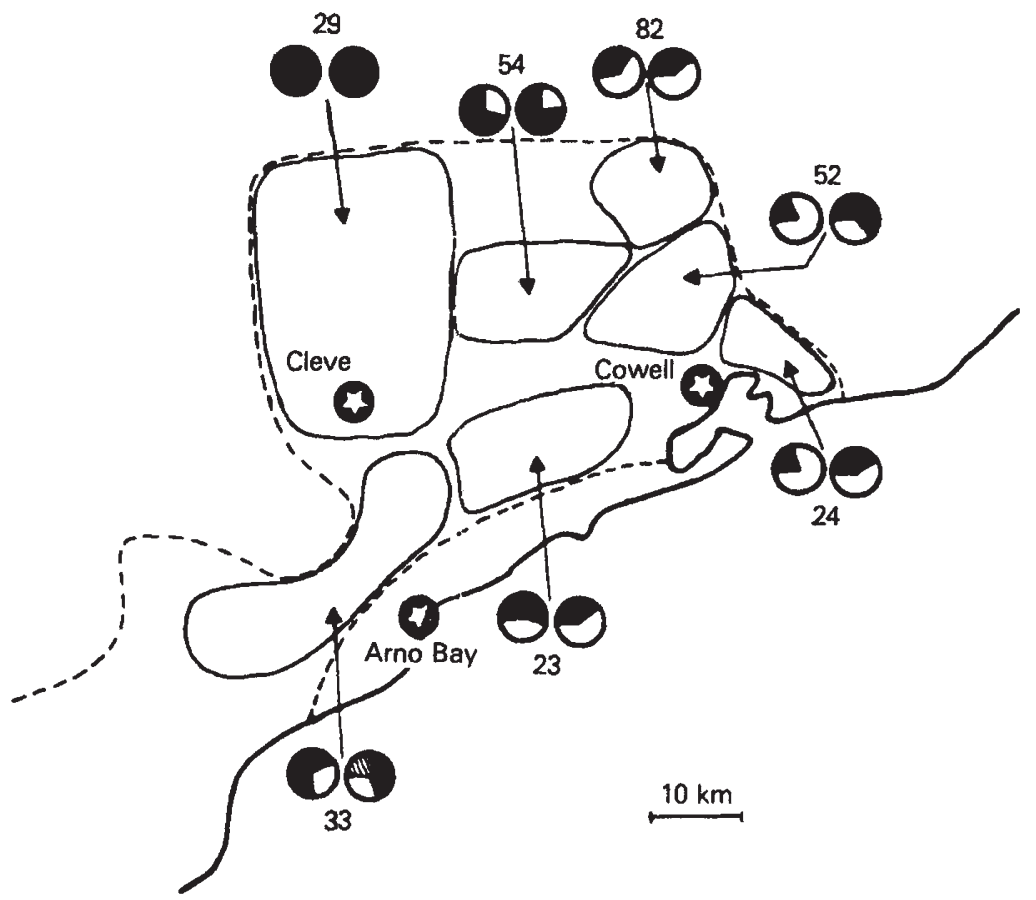

Fig. 3. The distribution of Ap. hydrosauri in the Cowell-Arno Bay area (Petney et al., 1982) showing the number of ticks sampled in each of seven regions, plus the frequency in each region of alternative alleles at the PGM locus (left hand circle, PGM a black, PGM b white) and at the GPI locus (right hand circle; GPI a white; GPI b black; GPI c striped).

was genetically similar to adjacent mainland populations even though the major host species $T$. rugosus has formed a distinct island race (Glauert, 1961). A small group of populations (Norseman (35), Rottnest Island (36), Lake Grace (37), Perth (39) and Yelben (38)) were separated from the other because of a high frequency of tile $\operatorname{Pep} D$ allele, but no geographical pattern emerged. There were no geographical clines from east to west over more than $2000 \mathrm{~km}$ of continuous distribution.

\section{(iii) Amblyomma limbatum}

The 15 sites from where Amb. limbatum were collected are shown in fig. 1. Table 4 shows the allele frequencies in those populations at 20 loci. The survey was incomplete because most of the populations sampled were clustered in a small section of the southern edge of the distribution of the species.

The mean heterozygosity per locus was on average $1.61( \pm 0.67)$ per cent per population. Using genetic distances based on 20 loci, the dendrogram (fig. 2) showed no evidence of genetical divergence, either within a thoroughly sampled small area (central South Australia) or over wide geographical separation. For instance samples from near Birdsville $(44,45)$ were genetically identical to samples from Red Cliffs (47) over $1000 \mathrm{~km}$ away. 


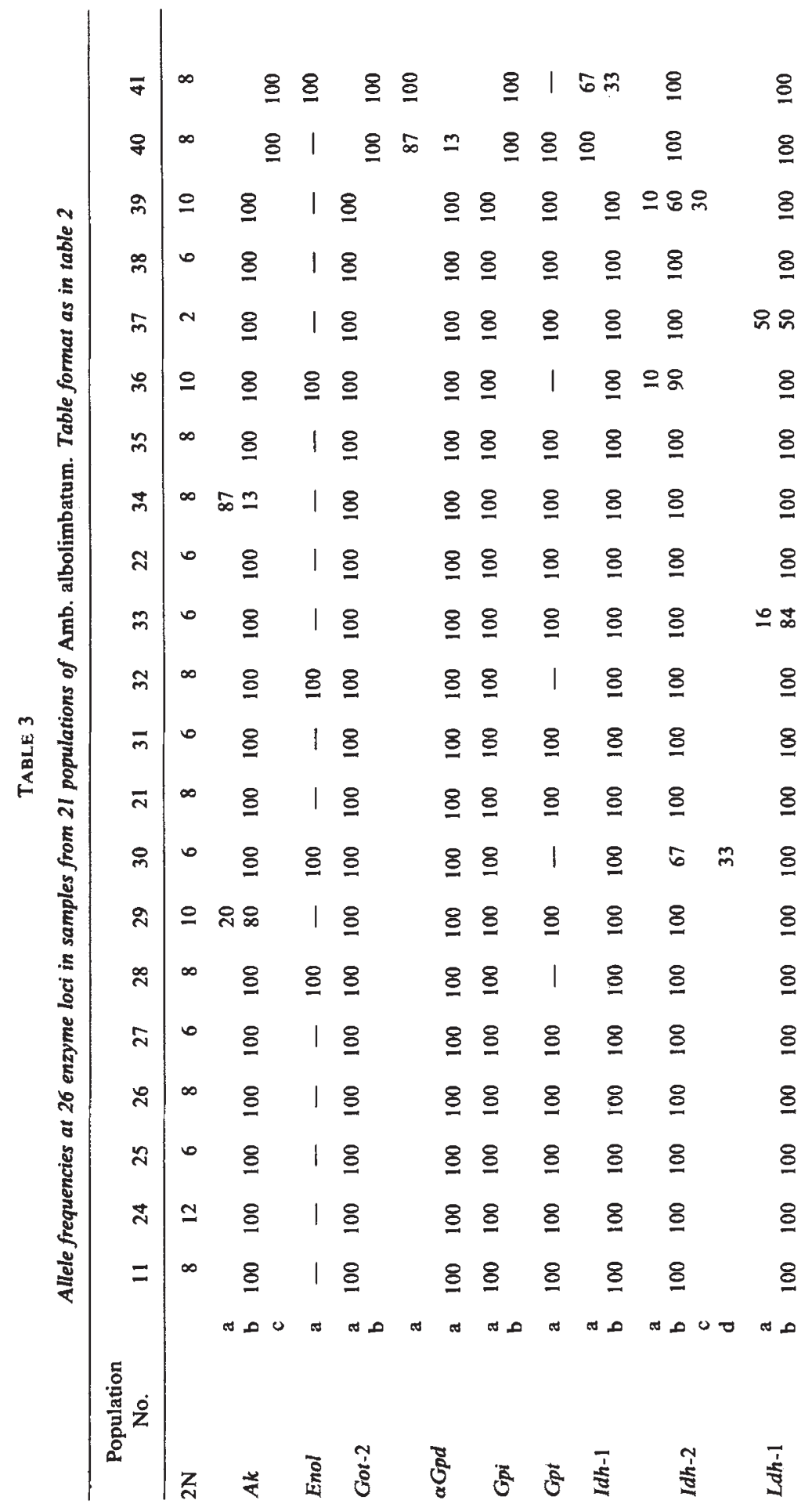




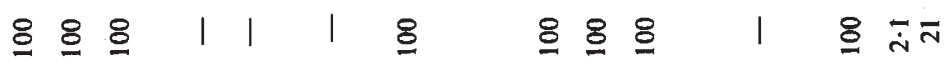

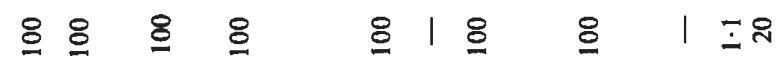

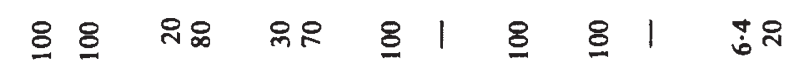

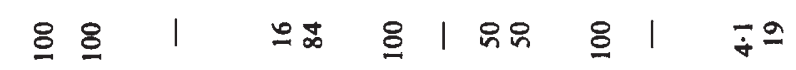

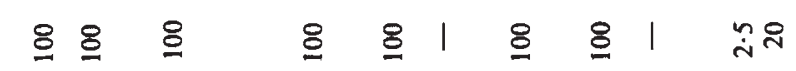

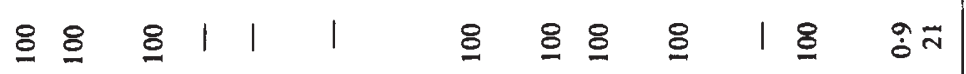

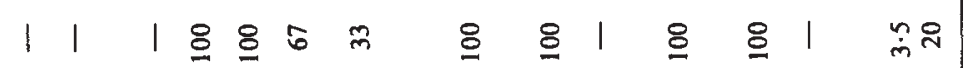

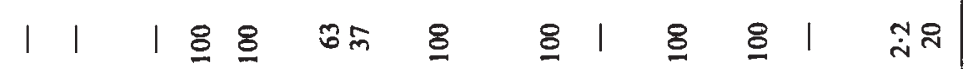
$1 \mid 1 \& 85 m$ \&

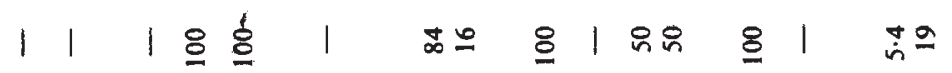

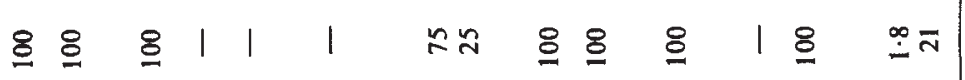

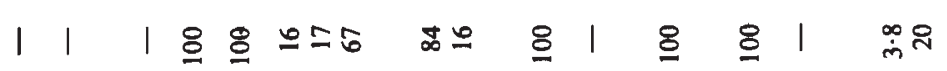

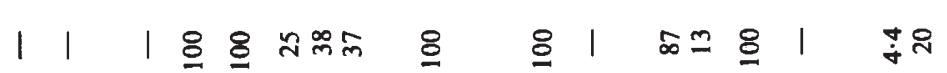

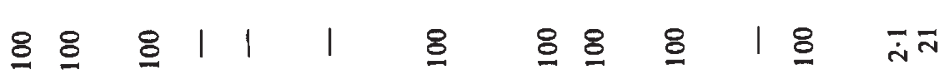

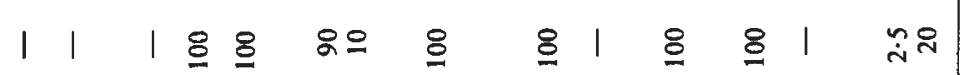
竞

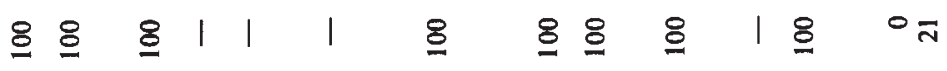

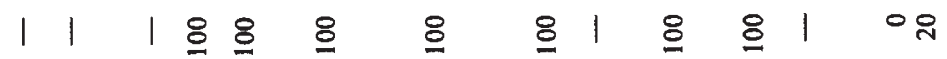
$1 \mid 1 \quad \& \& \& \quad \& \quad \& 1 \quad \& \quad \& 1 \quad 0 \%$ $1 \mid 1 \quad 8$ \&

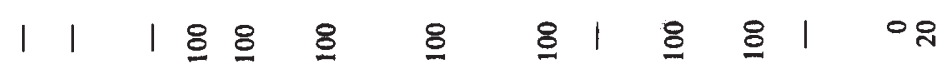

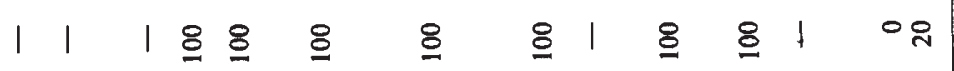

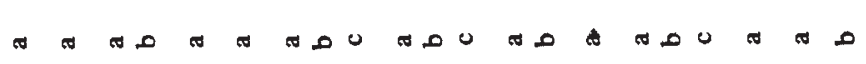

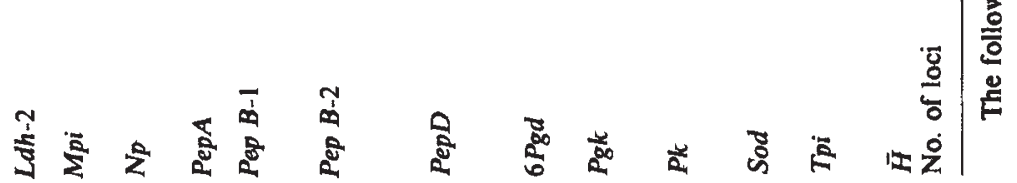




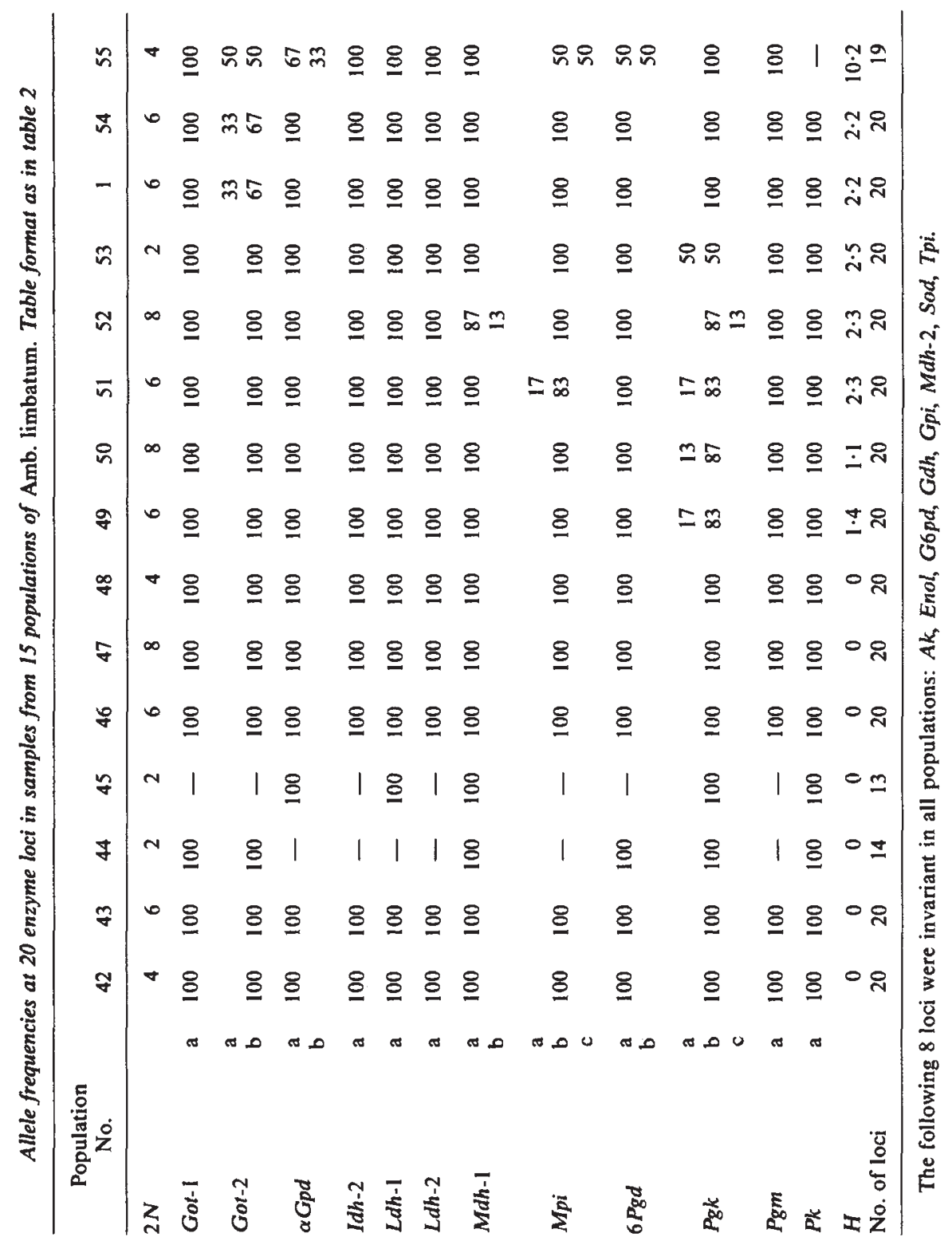


(iv) Other reptile tick species

In the sample from the $A p$. fimbriatum population $(2 \mathrm{~N}=4)$ only one locus $(P e p A)$ out of 22 was variable. The average heterozygosity per locus was 1.70 per cent. Two $A p$. undatum populations $(2 \mathrm{~N}=2$ and 6$)$ were monomorphic for the same alleles at 17 loci. Out of 22 loci only one (Idh-2) was recorded as variable in one of the three populations $(2 \mathrm{~N}=6,6$ and 4$)$ of the undescribed Amblyomma species. These samples were almost identical genetically despite the restriction of populations of this species to isolated rocky outcrops (Sharrad, pers. comm.).

\section{Discussion}

\section{(a) The prediction}

(i) Within population variability

Price (1977) predicted that parasites should exist as small relatively homogeneous populations. Reptile ticks remain immobile while detached, ensuring that they stay in the habitat of their host (Petney et al., 1983). They clump together while waiting for hosts (Bull, 1978a), probably by using aggregation pheromones (Petney and Bull, 1981). This behaviour reduces dehydration, increases the probability of detecting a host (Trevorrow et al., 1977, Petney and Bull, 1981), and increases the chance that related ticks will remain in one group and attach to the same host. Mating takes place on the host (Andrews and Bull, 1980), before females detach and lay their eggs (Sharrad, 1980). Reptile ticks disperse passively by limited host movement (Bull, 1978b, Satrawaha and Bull 1981). Local mixing of a tick population can result from the overlap of home ranges of hosts, and host pairing during spring. Thus tick populations are predicted to consist of related individuals restricted to small areas with low gene flow between areas. Inbreeding within areas should lead to low genetic variability in populations.

The theoretical considerations of Levins (1962) lead to the same prediction. He suggested that when small populations face relatively large spatial differences of habitat quality, for instance between host and non-host, they will become monomorphic and specialised to the local resource. Price (1977) pointed out that parasites exploit extremely coarse-grained environments making these conclusions particularly appropriate.

\section{(b) The test}

Consistently low levels of variability within populations were found in six species of reptile ticks taken from 65 populations. Nevo (1978) calculated that the average heterozygosity from 93 invertebrate species (mainly nonparasites) was $11 \cdot 23( \pm 0.75)$ per cent. The heterozygosity levels from reptile tick species (1.61-2.47 per cent) were considerably lower, supporting the predictions made by Price (1977). There are two potential sources of bias when comparing our data with previous studies.

a) The sample size for many populations was low, and real variation existing in the populations may not have been detected. For instance at the PepD locus in Amb. albolimbatum two alleles varied in frequency between 
populations with no consistent geographic pattern, indicating that a widespread polymorphism at this locus may have been concealed because of the small samples. However, at most loci many conspecific populations shared the same major allele, suggesting that variants at those loci were uncommon, and that genetic variation was adequately sampled. Increased sample size in Ap. hydrosauri from Tickera and Cape Naturaliste did not lead to increase in the estimated mean heterozygosity. Nei (1978) and Gorman and Renzi (1979) showed that small samples can be used to estimate heterozygosity and genetic distance where the average heterozygosity is low.

b) The enzyme loci chosen (Johnson, 1974) and the electrophoretic support medium (Johnson, 1976) can influence estimates of heterozygosity. Surveys using the same enzymes and cellogel as the support medium have revealed high levels of genetic variability in invertebrates and levels comparable with other surveys among vertebrates (Baverstock et al., 1977a, 1977b, $1980 \mathrm{~b}$, Richardson and McDermid, 1978, Daugherty et al., 1981, Adams et al., 1984).

The remarkably low level of variation in reptile ticks must be contrasted with the discovery by Healey $(1979 a, 1979 b)$ of extensive variation at two enzyme loci in Irish populations of the sheep tick Ixodes ricinus. Because the sample of loci is much smaller these results are not strictly comparable with the present study. However they imply that our findings may not be general for all tick species. This could be explained, in retrospect, because the reptile ticks follow much more closely the form of parasite ecology envisioned by Price (1977) when developing his hypothesis. Reptile ticks must become adapted to only one or two common reptile hosts in any area (Bull, 1978a, Bull et al., 1981). Host individuals are generally solitary and slow dispersing, so resources are patchy and gene flow low. On the other hand $I$. ricinus, particularly as larvae and nymphs, have a wide range of hosts (Milne, 1945, 1948) including reptiles, birds and mammals. Also the major host of adult $I$. ricinus are sheep, which live in flocks so that ticks have a choice of host individuals and stock movement by farmers would also allow gene flow between tick populations. These ecological differences indicate that reptile ticks are more likely to form small homogeneous populations than are sheep ticks.

\section{(ii) Between population variability}

\section{(a) The prediction}

Price (1977) predicted that parasites should have a higher rate of evolutionary change and speciation than non-parasites. In reptile ticks low host mobility (Bull, 1978a, Satrawaha and Bull, 1981) should reduce gene flow between adjacent populations, and with high fecundity, high mortality of juvenile stages and a relatively short life history (Bull and Sharrad, 1980) isolated gene pools could diverge rapidly through stochastic processes or adaptation to different host populations. Price (1977) claimed there is a high incidence of sibling species and of differentiated races within species among parasitic taxa, because of the higher evolutionary rate of parasites.

\section{(b) The test}

Because of the difficulty in estimating evolutionary rates within reptile ticks without a time scale, it was assumed that a high evolutionary rate 
would be reflected in contemporary taxa by a high incidence of local population divergence. Divergence was assessed by comparing estimates of genetic distance between reptile tick populations with those from other studies (e.g., Ayala, 1975).

Caution is needed in these comparisons because if genetic differences accumulate at different rates in different taxa (Avisa and Aquadro, 1982), then taxa with the same genetic distances between populations do not necessarily have the same evolutionary rates. The genetic distance estimates between conspecific tick populations were normally less than 0.06 units, falling within the range of genetic distances recorded between local populations in other (non-parasitic) invertebrate taxa, but lower than that between semi-species or subspecies (Ayala, 1975). The genetic discontinuities which Price (1977) envisioned in parasite populations were either uncommon in ticks or undetected by the electrophoretic assay.

Some divergence was found. Populations of Ap. hydrosauri, geographically isolated in Western Australia were electrophoretically distinct from eastern populations (Andrews and Bull, 1983). This allopatric divergence is not remarkable, in that it might be expected in either parasitic or nonparasitic taxa.

More relevant to Price's (1977) predictions are the two cases we detected where there was genetic divergence within a geographically continuous range. In both Ap. hydrosauri on Eyre Peninsula (fig. 3), and Amb. albolimbatum near Carnarvon (table 3 ), genetic differences were maintained over short distances. In the latter case a genetic distance of over 0.5 units suggests there has been a long period of divergence. In neither case were the diverged populations infesting a different host species. Since both cases involve populations at the edge of the species range (Sharrad and King, 1981, Petney et al., 1982), the alternative hypothesis of allopatric differentiation followed by secondary contact cannot be eliminated.

Our results suggest that reptile tick species normally contain similar rather than highly differentiated populations. An implication is that tick taxa are not undergoing the rapid evolutionary change which Price (1977) predicted for parasites. Adaptive changes related to local host populations either have not occurred, or not been detected in this study. Our data support the conclusions of Avise and Aquadro (1982) that taxa with low variability within populations usually have low genetic distances between populations. We found no evidence that reptile tick populations in Australia were differentiatiating at a faster rate than non-parasite populations.

Acknowledgements. This work was funded by a grant from the Australian Research Grants Scheme. Among the many people who collected ticks for us on their various field trips were M. Bamford, P. Baverstock, J. Choate, B. Fergusson, S. Habel, M. Huster, D. King, F. Odendaal, T. Petney, J. Popper, P. Robinson, P. Roper, R. Satrawaha, T. Schwaner, R. Sharrad, M. Thompson, B. Weavers, J. Whinray and D. Williams. Laboratory assistance was provided by S. Pappalardo and B. Sanderson. K. White typed the manuscript. Critical comments were provided by P. Baverstock, D. Hayman, J. Hughes, P. Mather and D. O'Dowd.

\section{REFERENCES}

ADAMS, M., BAVERSTOCK, P. R., SAUNDERS, D. A., SCHODDE, R. AND SMITH, G. T. 1984. Biochemical systematics of the Australian cockatoos (Psittaciformes: Cacatuinae). Aust. J. Zool., 32 (in press).

ANDREWS, R. H. AND BULL, C. M. 1980. Mating behaviour in the Australian reptile tick Aponomma hydrosauri. Anim. Behav., 28, 1280 1286. 
ANDREWS, R. H. AND BULL, C. M. 1983. Premating reproductive isolation between geographically isolated populations of an Australian reptile tick. J. Parasitol., 69, 1125-1130.

AVISE, J. C. AND AQUADRO, C. F. 1982. A comparativie survey of genetic distances in the vertebrates. Evolut. Biol., 15 151-185.

AYALA, F. J. 1975. Genetic differentiation during the speciation process. Evolut. Biol., 8, 1-78. BAVERSTOCK, P. R., WATTS, C. H. S. AND COLE, S. R. $1977 a$ Electrophoretic comparisons between allopatric population of five Australian Pseudomyine rodents (Muridae). Aust. J. Biol. Sci., 30, 471-485.

BAVERSTOCK, P. R., WATTS, C. H. S. AND COLE, S. R. 1977b. Inheritance studies of glucose phosphate isomerase, transferrin and esterases in the Australian hopping mice, Notomys alexis, $N$. cervinus, N. mitchellii and N. fuscus (Rodentia: Muridae). Anim. Blood Groups Biochem. Genet., 8, 3-12.

BAVERSTOCK, P. R., WATTS, C. H. S., ADAMS, M. AND GELDER, M. 1980. Chromosomal and electrophoretic studies of Australian Melomys (Rodentia: Muridae). Aust. J. Zool., 28, 289-303.

BULL, C. M. 1978a. Heterogeneity of resource utilization in a population of the Australian reptile tick, Aponomma hydrosauri (Denny). Ecol. Entomol., 3, 171-179.

BULL, C. M. $1979 b$. Dispersal of the Australian reptile tick Aponomma hydrosauri by host movement. Aust. J. Zool., 26, 689-697.

BULL, C. M. AND SHARRAD, R. D. 1980. Seasonal activity of the reptile tick, Aponomma hydrosauri (Denny) (Acari: Ixodidae) in experimental enclosures. J. Aust. Entomol. Soc., $19,47-52$.

BUll, C. M., ShaRRAD, R. D. AND PETNEY, T. N. 1981. Parapatric boundaries between Australian reptile ticks. Proc. Ecol. Soc. Aust., 11, 95-107.

DAUGHERTY, C. H., BELL, B. D., ADAMS, M. AND MAXSON, L. R. 1981. An electrophoretic study of genetic variation in the New Zealand frog genus Leiopelma. New Zealand J. Zool., $8,543-550$.

GLAUERT, L. 1981. A Handbook of the Lizards of Western Australia. W.A. Naturalists Club, Perth.

GORMAN, G. C. AND RENZI, J. 1979. Genetic distance and heterozygosity estimates in electrophoretic studies: effects of sample size. Copeia, 1979, 242-249.

HEALY, J. A. 1979a. Phosphoglucomutase polymorphism in the tick Ixodes ricinus. Parasitology, 78, 7-18.

HEALY, J. A. $1979 b$. Analysis of $\alpha$-glycerophosphate dehydrogenase variability in the tick Ixodes ricinus (Acari: Ixodidae). Genetica, 50, 19-30.

JOHNSON, G. B. 1974. Enzyme polymorphism and metabolism. Science, 184, 28-37.

JOHNSON, G. B. 1976. Hidden alleles at the $\alpha$-glycerophosphate dehydrogenase locus in Colias butterflies. Genetics, 83, 149-167.

LEVINS, R. 1968. Evolution in Changing Environments. Princeton University Press, Princeton, N.J.

MILNE, A. 1945. The ecology of the sheep tick, Ixodes ricinus L. Host availability and seasonal activity. Parasitology, 36, 153-157.

MILNE, A. 1948. The ecology of the sheep tick, Ixodes ricinus $L$. Host relationships of the tick. Part 2. Observations on hill and moorland grazing in northern England. Parasitology, 39, 173-197.

NEI, M. 1972. Genetic distance between populations. Amer. Nat., 106, 283-291.

NEI, M. 1978. Estimation of average heterozygosity and genetic distance from a small number of individuals. Genetics, 89, 583-590.

NEVO, E. 1978. Genetic variation in natural populations: patterns and theory. Theor. Pop. Biol., 13, 121-:77.

OLIVER, J. H. AND BREMER, K. C. 1968. Cytogenetics of ticks. III. Chromosomes and sex determination in some Australian hard ticks (Ixodidae). Ann. Entomol. Soc. Amer., 61, 837-844.

PETNEY, T. N. AND BULL, C. M. 1981. A non-specific aggregation pheromone in two Australian reptile ticks. Anim. Behav., 29, 181-185.

PETNEY, T. N., ANDREWS, R. H. AND BULL, C. M. 1983. Movement and host finding by unfed nymphs of two Australian reptile ticks. Aust. J. Zool., 31, 717-721.

PETNEY, T. N., BULL, C. M. AND ANDREWS, R. H. 1982. A stable boundary between two species of reptile ticks on Eyre Peninsula, South Australia. Trans. Roy. Soc. S. Aust., 106, 159-161.

PRICE, P. W. 1977. General concepts on the evolutionary biology of parasites. Evolution, 31, $405-420$. 
RICHARDSON, B. J. AND MCDERMID, E. M. 1978. A comparison of genetic relationships within the macropodidae as determined from allozyme, cytological and immunological data. Aust. Mammal. 2, 43-51.

ROBERTS, F. H. S. 1970. Australian Ticks. C.S.I.R.O., Melbourne.

SATRAWAHA, R. AND BULL, C. M. 1981. The area occupied by an omnivorous lizard, Trachydosaurus rugosus. Aust. Wildl. Res., 8, 435-442.

SHARRAD, R. D. 1980 . Studies of the factors which determine the distributions of three species of South Australian ticks. Ph.D. Thesis, University of Adelaide.

SHARRAD, R. D. AND KING, D. R. 1981. The geographical distribution of reptile ticks in Western Australia. Aust. J. Zool., 29, 861-873.

SNEATH, P. H. A. AND SOKAL, P. R. 1973. Numerical Taxonomy. W. H. Freeman, San Francisco. TREVORROW, R. L., STONE, B. F. AND COWIO, M. 1977. Aggregation pheromones in two Australian hard ticks, Ixodes holocyclus and Aponomma concolor. Experientia, 33, 680-682. 